\title{
The Analysis of Financial Relationships How to Affect Financing Dilemma of Small and Medium-Sized Enterprises
}

\author{
Yinghui Li
}

\begin{abstract}
Since the reform of state-owned enterprises, small and medium-sized enterprises gradually become the leading engine of our national economic growth, but due to the economic development of our country is still at the stage of transformation with imbalanced credit rationing, imperfect financial system and capital market and other issues which have serious impacts on the financing procession of small and medium-sized enterprises, leading to its limited access to credit resources. Under this background, combining with the related theory, this paper is based on the reputation and relationships proposed by Allen (2005) to study whether the establishment of financial relationships can help small and medium-sized enterprises obtain stable and adequate credit support or not, so as to ease the external financing constraints, and then put forward countermeasures and suggestions which can lay the foundation for small and medium-sized enterprises' further development and expansion.
\end{abstract}

Index Terms-Financing constraints, financial relationships, small and medium-sized enterprises.

\section{INTRODUCTION}

In China, with the deepening reform of economic system, small and medium-sized enterprises have become an important force to promote the construction of socialist market economy, more importantly, they also have played an important role in promoting economic prosperity, increasing employment and maintaining social stability, but financing constraints is becoming an important bottleneck problem restricting its development [1].

For small and medium-sized enterprises in our country, there are mainly two channels of financing: internal financing and external financing. Internal financing refers to the process to make enterprise internal financing convert into investment which is the major source of small and medium-sized enterprises' founds. External financing means the enterprises to raise funds mainly through bank loans, issuance of stocks, corporate bonds and other ways. However, from the annual average data, relying on internal financing solely can't meet all the needs of small and medium-sized enterprises to raise money, as a result, they do have to regard sovereignty financing and debt financing as the main external financing ways. However, listing threshold is too high in our country to

Manuscript received April 18, 2015; revised June 10, 2015.

Yinghui $\mathrm{Li}$ is with Shandong University of Finance and Economics, Jinan, Shandong, China (e-mail: yasi_mingchao@ 126.com). make many small and medium-sized enterprises to solve this financing dilemma through sovereign capital financing, thus they gain funding supporting mainly through the form of liability. After 2006, although the reform of state-owned enterprises oriented by the four major state-owned banks achieved periodic success, which improved the market level of domestic banking, but there are still many non-market factors exist affecting bank credit decisions because of central bank credit control and local government intervention. Therefore, under the current financial system, small and medium-sized enterprises are vulnerable to bank credit discrimination and the cost of financing is too much higher which makes it difficult to obtain credit and financing support from formal channels, and that is why small and medium-sized enterprises are facing serious financing difficulties [2].

In addition to its own characteristics such as the short-time establishment, the dependence and fluctuation of market and the difference of credit assurance ability made it difficult to obtain outside trust from investors, banks or other factors, the financing difficulties of small and medium-sized enterprises are also affected by external factors mainly lies in bank credit crunch, rising raw material prices and labor costs which lead majority of small and medium-sized enterprises to completing the primitive accumulation of capital mainly through private capital investment. When the development of the small and medium-sized enterprises' development came to a certain scale, especially during the period of transition from labor-intensive industry to technology-intensive industry, external financing is becoming more and more urgent while internal financing could not meet all their demand of capital. The deeper reason lies in China's economic development is the stage of transition, the excessive political interference and the imperfect financial system leads to uneven distribution of resources, especially for small and medium-sized enterprises, as a result, there is no wonder that financing constraints is increasingly become a main obstacle to restrict their development.

As an important factor affecting the growth of small and medium-sized enterprises, the influence of institutional environment has penetrated the whole process of strategic management and strategic potential income. Given priority to with Allen, some scholars studied, contrasted the formal legal system and financial system of China, and the alternative mechanism of formal governance mechanism with the connection between these systems and China's economic development. As one of the world's largest and fastest developing economies, China is an important counterexample 
in such researches compared with other countries in the aspect of legal, institutional, financial and economic development. That's why Allen (2005) put forward the famous theory of "China Puzzle", namely, although the legal and financial system and institution development in China are not perfect, its economic development speed is still keeping fast. More importantly, in Chia, the perfection degree of legal and financial system applicable to small and medium-sized enterprises are far less than state-owned enterprises and listed corporations, but its speed of development is far more quickly than the latter two. Under this background, the alternative mechanisms and institutions are not only play an important role in supporting the development of small and medium-sized enterprises, but also become one best substitute taking place of the formal governance mechanism and financing alternatives, especially the reputation and relationships mechanism which is the typical one with more and more small and medium-sized enterprises tend to establish various relationships(e.g. political connections and financial relationships)with government, banks to break through both financing constraints and dilemmas at the same time [3].

With the gradual deepening reform of China's finance, politics and other aspects, we truly believe that financial relationships is an important part of the reputation and relationships mechanism emphasized by Allen. Financial relationships refers to hiring executives with a background of financial institutions to become a member of the senior corporate management, utilizing relationships to transfer "soft information" of the business development, acquiring part of the synergy value or by taking a stake to forge the personnel association, financial association, especially with banks, which can help to reduce sensitivity of borrowed capital, ease financing constraints, strengthen contacts with financial institutions more closely, establish harmonious relationship between the shareholders, and help the company to obtain key resources in the end.

\section{THEORETICAL BACKGROUND}

To some extent, the emergence of alternative mechanism can make up for the gap and shortage of formal mechanism, help to reduce the information asymmetry and friction of the credit market. Embodied in these following areas:

\section{A. Social Capital Theory}

The leading position of Confucianism in China's traditional culture makes the establishment and application of interpersonal relationship attach great importance both in daily life and business activities, thus, the relationships is not only a kind of resources, but also a kind of social capital and an access to resources. From the perspective of credibility and integrity, Bian Yanjie and Qiu Haixiong (2000) emphasized that every enterprise is not an isolated individual, but a network note in the economic field and the ability of enterprise to obtain scarce resources through these connections which will convert into the social capital of the enterprise. There are mainly two ways for social capital to influence the allocation of resources: trust mechanism and opportunity costs which can help to reduce adverse selection along with moral hazard behavior and default risk in order to access to scarce resources. Based on this, the economic links of enterprises can be summarized three categories as: the vertical linkages, the horizontal linkages and social connection, including political relationships belongs to vertical integration and financial relationships belongs to horizontal linkages [4].

\section{B. Asymmetric Information Hypothesis}

During the financing process of small and medium-sized enterprises, information asymmetry refers to financial institutions as the information vulnerable party could not determine enterprise's credit status and repayment capacity only through its status and development prospect, let alone small and medium-sized enterprises ,triggering a "parsimony and caution of credit" phenomenon. Therefore, the higher the degree of information asymmetry is, the lower the level of credit decision made by small and medium-sized enterprises becomes, for instance, high cost and low credit, and thereby deepening the financing difficulties of small and medium-sized enterprises. Based on this, the relationship between Banks and enterprises can be divided into relational financing and arm-length financing. The access to information of arm-length financing mainly through public disclosure which is suitable for the large and mature enterprises, while due to the low number of investors of relational financing and less "free riding" behavior, investors can provide both information screening and subsequent supervision at the same time, thus reducing the third party qualification verification services. For small and medium-sized enterprises, the advantages of relational financing includes confidential internal information, inter-temporal share and the cost of loans with future earnings for initial earnings losses. To measure the relationship between banks and enterprises, domestic researchers commonly reference seven indexes put forward by Petersen: enterprise existing period; the loan term; borrowing concentration; the concentration of bank organization; whether obtain loans from bank before; whether need other services or not; the number of non-bank financial institutions.

In conclusion, relational financing in mature capital market mainly has two characteristics: one is clear and equal property right relations, the other one is higher degree of banking industry concentration which has the ability to make the loan price independently and flexibly. Due to the banking industry in our country does lack the conditions above, so it is different from a mature capital market.

\section{Credit Rationing Theory}

Lots of scholars defined the credit rationing of financial market from different angles. Stightz and Weiss (1981), the founders of the credit rationing theory, described credit rationing as the way of banks to screen customers is based on the risks and benefits, rather than the interest rate pricing mechanism which is determined by equilibrium price and cost. There are two categories of this specific performance: the first kind is to implement credit quota for all customers in order to meet part of their credit needs; the second kind is to implement different treatment on different customers in the financial market which makes only part of the customers' 
credit needs can be satisfied. On the basis of the analysis of the two kinds of credit model, Stightz and Weiss argued that we should focus on reducing interest rate control and government intervention, improving the requirements of information disclosure and increasing risk management measures, only in this way can we promote the efficiency of resources allocation. This conclusion has significant enlightenment and inspiration to the reform of operating mechanism of credit market in china. At present stage of China's financial market, the two types of credit rationing may coexist: the first type of credit rationing mainly emerged in the resources fight between homogeneous enterprises, such as the state-owned enterprises would like to apply for credit financing to meet their investment needs, and the government tends to coordinate credit resources through administrative intervention. And the second type of credit rationing is relatively common in different property natures of enterprises or with different scale. The former mainly due to administrative intervention or hidden political guarantee which lead to a phenomenon of "credit crunch" while the latter maybe due to two companies' operation stability, social capital, asset size, collateral conditions, reputation problems caused by information asymmetry degree. As a result, banks tend to choose smaller enterprises with small business scale and risk to avoid risks [5], [6].

\section{Reputation Theory}

La Portal (1997) studied the importance of reputation and relationships and considered it important in maintaining cooperation. Nowadays, modern enterprises are paying more and more attention to the importance of reputation. At present, the existing reputation theory mainly includes reputation transaction theory and reputation information theory. Based on the thought of reputation is a kind of assets, reputation transaction theory argued that reputation is a long-term intangible assets which can be established, invested and managed pointing out that as a commitment mechanism, reputation capital can effectively avoid the opportunism behavior and emphasized the reputation transaction, namely, reputation can be traded in any kind of market transactions. What is more, corporate reputation value will increase with the deepening customers' cognition of enterprise. Reputation information theory considered that specific information are formed by virtue of history characteristics and exchanged between various stakeholders which can form reputation information flow at the same time to limit the information asymmetry effectively, improve information transparency during the transactions, reduce transaction cost and achieve a win-win goal. Of course, we could not ignore that the transfer procession of reputation information is not perfect yet due to the market failed to identifying all kinds of reputation with different quality. Therefore, it is important for enterprises to attach importance to the effectiveness problem during reputation management [7].

\section{THE WAY OF FINANCIAL RELATIONSHIPS HOW TO INFLUENCE SMALL AND MEDIUM-SIZED ENTERPRISES' FINANCING}

At present, with the rapid development of the socialist market economy, the continuous improvement of financial market produced profound influences on the development of private enterprises as follows: the improvement of financial market exacerbated the financial competition while providing abundant financing resources for private enterprises; it promotes the deepening reform of China's banking industry; moreover, it can also promote popularization and improvement of corporate credit database technology [8].

Financial relationships affect small and medium enterprises' credit financing mainly through the relationship mechanism, communication mechanism and financial skills mechanism with the following ways:

Firstly, financial relationships can promote the accumulation of social capital. The key factor of small and medium-sized enterprises success lies in the use of social capital to obtain scarce resources and make a reasonable distribution. And the way of financial relationships manly through the establishment of direct or indirect social network which can help to promote the mutual trust of trading, increase the supply of corporate funds, reduce the cost of default and also to obtain relevant policy support. As Allen (2005) study found that, in China, the alternative mechanisms such as the social capital can largely make up for the lack of protection from legal, financial and other formal mechanisms.

Secondly, financial relationships can reduce the degree of information asymmetry. On the one hand, the establishment of financial relationships can help transfer the "soft information" of operation and development, improve the degree of information symmetry between enterprise and outside investors, adjust the pattern of information imbalance, constraint the lending moral risks, ensure the reasonable deal, push forward the cooperation among organizations and reduce transaction costs; On the other hand, the establishment of financial relationships will affect financial institutions and decision-making, enhance enterprise's credit and reputation, solve the information asymmetry between financial institutions and enterprises to a certain extent, and create innovative financing options with the help of financial association to ease the private enterprise financing constraints.

Thirdly, from the point of reputation theory, reputation can create wealth. An enterprise owned ample reputation capital can not only enable banks to believe that it has the ability to perform its debt contract, but also can attract outside investors with its reputation advantage. Reputation can bring a certain value to enterprise with a high cost. Especially at the start-up period, reputation capital was at an unstable place due to historical reasons. However, since the 1990s, a large number of start-up companies obtain reputation relying on strategic alliances or indirect guarantee. Specially, the potential security and reputation of private enterprises based on the establishment of financial relationships can strengthen the confidence from enterprise staff, upstream suppliers and outside investors, financial institutions and government in private enterprises to increase financial support and alleviate financing constraints of private enterprises [9], [10].

Finally, financial relationships can enhance the competitiveness of enterprises. The establishment of financial relationship is beneficial to reduce investment mistakes, optimize the enterprise capital management, create more cash 
flow for enterprises, thus improve enterprise financing skills and broaden the financing channels.

\section{CONCLUSION}

Therefore, if we want to solve the financing dilemma of small and medium-sized enterprises, we should start with the conception of institutional innovation which is fundamental including enterprise internal system, financial institution system, government policies and legal system to improve financing ability, promote the sustainable development of small and medium-sized enterprises.

A. Improve and Perfect the Internal Financing System of Small and Medium-Sized Enterprises to Strengthen Internal Financing Abilities

\section{1) Improve the financing system to raise more capital}

Small and medium-sized enterprises should establish a scientific decision-making mechanism, improve the financing system, reduce costs and improve its quality in order to update product, improve market competitiveness and internal financing ability.

2) Improve the information disclosure system to alleviate financing predicament

The financing difficulties of small and medium-sized enterprises are mainly caused by the information asymmetry, the main way of solving this problem is to improve the information disclosure system of capital required by the market, establish the credit guarantee system. The information disclosure system is established on the basis of borrowers and enterprise management and committed to solving the asymmetric information between the two. Small and medium-sized enterprises should gradually improve their repayment conditions and ability, credit rating and other financing management system especially the information disclosure system.

3) Establish a clear and open property rights system to enhance enterprises' core competitiveness

The property right reform of small and medium-sized enterprises can not only promote the transformation of enterprises, increase profits, improve the internal financing ability, but also can cause the enterprise financing growth, seek direct financing channels, optimize financing structure which is beneficial to enhance the enterprise capital strength, overcome the unfavorable factors and high asset-liability ratio, especially considering the short-term effect. As a result, to accelerate the pace of property right reform of small and medium-sized enterprises will bring both direct and indirect influence on the financing dilemma.

Although small and medium-sized enterprises have established a clear ownership system, the definition of property rights between venture members and family members is very vague. During the development procession, the unclear property rights and self-interest nature of people in economic activities seriously influenced the stability and development of enterprise. Therefore, we can draw lessons from experience in foreign capital market that attract social capital through going public and entrepreneurial families only obtain certain controlling interest. This open ownership structure can improve diversity and liquidity of property rights, establish a main body with risk sharing, mutual supervision and mutual support of multivariate investment and a structure with relatively standard corporate governance.

\section{B. Establish a Flexible and Effective Financial \\ Supervision System, Make the Change for the Management System Model and Provide Institutional Channels for Small and Medium-Sized Enterprises' Financing \\ 1) Innovate financing form and expand financing channels for small and medium-sized enterprises}

The innovation of financing form can help disperse and reduce the risk from financing parties. Practice has proved that asset-based financing is an effective method to reduce the risk and solve the financing difficulties of small and medium-sized enterprises. Especially when it comes to the financing options of small and medium-sized enterprises according to their own assets to meet the short-term or long-term capital demand, expand financing channels, make full use of the enterprise value of the assets.

2) Innovate the credit operation mechanism and management mode to meet small and medium-sized enterprises' financing demand

Financial institutions can develop a set of credit management system and operation mechanism suitable for the loan business in accordance with the characteristics of small and medium-sized enterprises, and provide strong support for their healthy development, what's more, they can also simplify loan procedures, improve work efficiency and authorize enterprises' working capital, bank acceptance, credit card business on the direct basis of the system and the corresponding inspection regulations.

\section{3) Innovate the credit mortgage guarantee system and method}

According to the status of small and medium-sized enterprises' financing mortgage guarantee system, we introduce the floating mortgage, pledge of accounts receivable, inventory of mortgage loans to improve the relevant business management system, operation procedures and its operability. These loans and insurance business can not only achieve the innovation of bank mortgage loan business and the external security mechanism, but also make the chattel mortgage of small and medium-sized enterprises more convenient. Therefore, the effective use of enterprise mortgage loan resources will lead to a systematic improvement.

\section{4) Change the management system model}

In summary, we can change the management system model with the following steps: change the concept step by step to place the development of small and medium-sized enterprises in an important position; authorize the city-level and county-level approval authority of entrusted loans to promote the development of small and medium-sized enterprises; adjust the practice of credit management to get rid of the "zero risk" requirements of credit from small and medium-sized enterprises; establish the corresponding constraint and incentive mechanism in order to achieve the dual purpose of credit risk control and efficiency; establish the effective risk 
regulation to reach a standard for corporate credit.

\section{The Government Should Speed up the Construction of Credit System, Promote the Reform of Capital Market Mechanism, and Innovate the Government Management System}

\section{1) Innovate credit guarantee system and relevant supporting system}

Differences of social credit environment is one of the biggest obstacles restricting small and medium-sized enterprises' financing. The purpose of establishing the credit guarantee system is to give full institutional guarantee of integrity behavior, punish the illegal discreditable behavior and increase the violation cost.

\section{2) Improve capital market system to construct a multi-level and multi-form capital market}

Establish a diversified equity market with the purpose of providing venture capital for small and medium-sized enterprises; establish a multi-level capital market and provide investment channels for small and medium-sized enterprises; develop the bond market for them to broaden the financing channels.

\section{3) Innovate management system in the view of small and medium-sized enterprises}

The government should change the angle of view, foster small and medium-sized enterprises' economic service system and provide a community service system which is multi-level, multi-channel and multi-function. First of all, we should strengthen the macroeconomic regulation and governance function of the government and perfect the market system to create a better atmosphere for the development of small and medium-sized enterprises. Secondly, we should earnestly implement the national preferential policies and treatment for small and medium enterprises. Finally, make the sound economic policies and provide financing, tax, technology, information and other kinds of support for small and medium-sized enterprises to help the development of $\mathrm{d}$ scientific decision-making, improve the service efficiency of funds, and then solve the financing difficulties.

To sum up, it is a systematic project to solve the financing difficulties of small and medium-sized enterprises with the need of multi-pronged and benign interaction. Only in this way can we fundamentally solve this problem, provide a good institutional environment for the development of small and medium-sized enterprises, and then promote the sustained, stable economic development of China[11], [12].

\section{ACKNOWLEDGMENT}

This paper was completed under the guidance of the mentor who conducted the research, so the author would like to thank the mentor firstly. As far as the author knows, no conflict of interest exits in the submission of this paper. And the author would like to declare that the work described was original research that has not been published previously, and not under consideration for publication elsewhere, in whole or in part.

\section{REFERENCES}

[1] D. Jianping and Z. Yong, "An empirical research on financial ecological environment, banking association and debt financing Based on China's private enterprises," Journal of Accounting Research, vol.12, pp. 33-40, 2011.

[2] M. Majluf, "Corporate financing and investment decisions when firms have information that investors do not have," Journal of Financial Economics, vol. 13, 1984

[3] F. Allen, J. Qian, and M. Qian, "Law, finance and economic growth in China," Journal of Financial Economics, vol. 77, pp. 57-116, 2005.

[4] B. Yanjie and Q. Haixiong, "The social capital effect of enterprises," Journal of Chinese Social Science, pp. 87-99, 2000.

[5] J. J. Yu, "Review of theory of modern western reputation," Journal of Economic Survey, vol. 11, pp. 18-22, 2003.

[6] A. S. Weiss, "Credit rationing in markets with imperfect information," Journal of American Economic Review, vol. 71, no. 3, pp. 393-410, 1981.

[7] R. L. Portal, F. L. D. Silanes, A. Shleifer, and R. Vishny, "Trust in large organization American economic review," Journal of Political Economy, vol. 87, pp. 333-338, 1997.

[8] J. P. Deng and Y. Zeng, "Can financial relationships solve the financing constraints of private enterprises?" Journal of Financial Research, vol. 8, pp. 78-92, 2011.

[9] Z. Zheng, F. W. Liu, and Z. Q. Li, "The degree of marketization, Government intervention and corporate debt maturity structure," Journal of Economic Research, vol. 5, pp. 15-19, 2005.

[10] K. Gravens, "The reputation index: Measuring and managing corporate reputation," Journal of European Management, vol. 2, pp. 201-212, 2003.

[11] G. H. Jiang and P. H. Rao, "Macroeconomic policies and micro enterprises to expand new field of accounting and finance research," Journal of Accounting Research, vol. 3, pp. 11-13, 2011.

[12] H. J. Zhu, X. J. He, and X. Y. Chen, "Financial development, soft budget constraint and investment," Journal of Accounting Research, vol. 10 , pp. $64-71,2006$

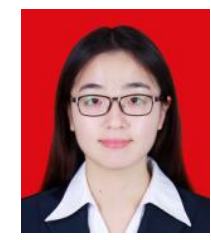

Li Yinghui was born in Jining of Shandong province, China in 1990. She received her degree in financial management from Shandong University of Finance and Economics, Jinan, Shandong, China from 2009 to 2013

She received her master degree in accounting from Shandong University of Finance and Economics, Jinan, Shandong, China during 2013-2015.

She worked in Rui Hua Certified Public Accountants as an intern during Jan.-Mar. 2015. In 2014, she worked in the Financial Department of Shandong province as an intern, and also worked in the International Musical Instrument Exhibition of Shanghai as a translator in 2010.

Miss Li was awarded the National Endeavor Fellowship, First-Class Scholarship for Excellent Students, "Triple-A" Student Award during 2013-2014, and also won the Third Prize of The National English Contest, First Prize of The English Speech Contest, First-Class Scholarship for Excellent Students during 2011-2012. 